\title{
Current Status: Mexican Medicinal Plants with Insecticidal Potential
}

\author{
Ludmila Elisa Guzmán-Pantoja, Laura P. Lina-García, \\ Graciela Bustos-Zagal and Víctor M. Hernández-Velázquez \\ Laboratorio de Control Biológico, Centro de Investigación en Biotecnología, \\ Universidad Autónoma del Estado de Morelos, Morelos, \\ Mexico
}

\section{Introduction}

Plants have been used for thousand of year as a source of bioactive substances for therapeutic, agricultural and industrial purpose; in this regard the search for compounds active on these sources is an alternative for development of agrochemicals (Dayane et al., 2009). The plans, their derivatives or extracts have been studied for different biological activities in economically important pests, assessing their toxic effects lethal, antifeedant, repellent, fumigant, growth regulation and deterrent to oviposition, among other (Isman, 2006; Singh and Saratchandra, 2005).

The ecological balance and the organisms of various ecosystems are vulnerable by excessive or careless use of pesticides in agricultural or urban system. In theory, through using these products is to provide enough food and pest control, in contrast, often cause undesirable and dangerous environmental situations. Therefore, before to take a decision on the use of any pesticide, you should be aware that if the use of these substances is performed under controlled conditions and with full knowledge of its adverse properties, the survival of living things and balance of nature can become seriously affected (SEMARNAT, 2011).

The use of plants as a source of active compounds emerged as friendly alternative the indiscriminate use of synthetic products for pest control, which has causes toxicity to human health, biodiversity impoverishment, damage to beneficial organisms and favor the emergence of strains of pests resistant to these product, so it is common to increase the application rate risk to public health and the environment (Siqueira et al., 2000).

The rescue of rudimentary practices used by farmers in pest management is one of the options to find alternatives to the frequent use of synthetic pesticides. This report compiles information about the use of Mexican medicinal plants, native and introduced in the pest control mainly of the system agriculture and livestock primarily, and report an analysis of current status and recommendations for use botanical insecticides.

Currently investigations are conducted to determine the potential pesticide plant (used in herbal medicinal), its derivatives or extracts, such as several spices of the family Asteraceae, Euphorbiaceae, Solanaceae, Meliaceae,Convolvulaceae, Lauraceae, Piperinaceae, and Anonaceae, among other (López-Olguín et al., 2002; Pereda-Miranda \& Bah, 2003; Prakash \& 
Rao, 1997; Ramos, 2010; Rodríguez et al., 1982). For instance in the family Convolvulaceae, some species of the genus Ipomoea such as I. tricolor, I. batata and I. murucoides are traditionally used as nutricional, emetic, diuretic, diaphoretic, purgative (Pereda and Bah, 2003) and pesticidal agents (nematodes, insects, and weeds) (Jackson \& Peterson, 2000; Vera et al., 2009; Vyvyan, 2002).

\section{Botanic pesticide}

In ancient culture and in different parts of the world has existed for thousands of years ( 1500 before J. C.) empirical knowledge of the use of plants for pest control, for example, the neem in India, rotenone in East Asia and South America, pyrethrin in Persia (Iran) and sabadilla in Central and South America later botanical insecticides were introduced in Europe and Unite States (Weinzierl, 2000). Since the late 1800s to the 1940s, these products were widely used to protect crops and stored products. It was in the early 1940s and the 1950s which the development and commercial success of synthetic insecticides led to the abandonment of botanical insecticide in agriculture of the industrialized countries, as they won space on the market as products cheaper, effective, long-lasting and readily available. Only the botanical insecticides which remained in use in the Unite States after 1950, were pyrethrins (such aerosol spray and in home and industry) and nicotine (used primarily in the gardens). Already in the 1990s renewed interest stems from the use of botanical pesticides, because it is recognizes the impact on health and environmental that the synthetic insecticides cause, and their presence in food (Weinzierl, 2000).

Botanical pesticides are formulations of organic solvents and aqueous based on different parts of plants (crude extracts) or derivatives thereof, are prepared in powder or liquid concentrates that can be incorporated into talc or clay for application either concentrated or diluted in a solvent such as water, ethanol and petroleum ether, among others (Isman, 2008). These products consist of a group of active ingredients of different chemical nature (Isman, 1997). Preparations from plants such as pyrethroid, rotenone, neem, and citronella, commonly are formulated as liquid concentrates or extracts. The processed form of these products, are purified and isolated substances from plants through a series of extraction and distillation (Weinzierl, 2000).

Through different studies have found that the biological activity of botanical extracts pesticides it is different significantly depending on the species of plants, plant parts used for the preparation of the extracts, the physiological state of the part used, of the solvent extraction, and the insect species under study (Shaalan et al., 2005). Although these products are of natural origin cannot be assumed to be completely safe, some plant-derived compounds, such as nicotine are extremely toxic to humans, or when used several times in continuous time, can affect the natural biotic control of pests by their natural enemies. Therefore, it is important to use correctly the technique and safety equipment when working on the preparation and application of botanical extracts, and recognize the appropriate dose formulation and its use in a program of integrated pest management, which will help efficiently to obtain the benefits of these products. Despite there are many plants and chemical constituents known to have insecticidal properties or insectistatic, few have been used for commercial production. Issue that has been reviewed by several researchers as Graiger and Amhed (1988) and Isman (2008). The Use large-scale commercial of the plant extracts as insecticides began in the 1950s with the introduction of nicotine from Nicotiana tabacum, rotenone from Lonchocarpus sp, derris from Derris elliptica, and pyrethrum from flowers of Chrysanthemum cinerariaefolium (Isman, 2008). 
Gaugler (1997), mentioned concerning this that the inconvenient of these products are offset by its lower toxicity, higher levels of security and in addition to generally exhibit lower accumulation in the environment, characteristics that should be used to promote their sales (Silva et al., 2002). These products have the advantage of being generally compatible with other programs acceptable alternative integrated pest management, such as practices, cultivation of plants resistant to pests, pheromone oils, soaps, entomopathogenic, predators and parasitoids, among others (Brechelt, 2008). Botanical pesticides already registered and approved are promoted for organic crop production especially in industrialized countries and for production and postharvest food protection in developed countries (Rodriguez, 1997).

Actually in the Unite States the registration of the botanical insecticides request few requirements, for that reason allows a wide range of these products, including pyretrins, neem, rotenone, sabadilla, ryania, and nicotine. Essential oils are also sold although several of them do not have a complete record (Isman, 2006). In Latin America, it is common that the production of oil and botanical extracts for pest control is done without regulatory system and small scale for local use in low-income populations. As in all developing countries, lack of training of relevant legislations to regulate these products has complicated the registration process, this is the case of Mexico with the insecticide Biocrack ${ }^{\circledR}$ (garlic extract) Berni Labs who have gave the record seven year after starting its activities (Silva et al., 2002). On the other hand, Mexico allows the use of many products sold in the Unite States as the PHCTM NEEEMTM (31.2 g i.a. L $^{-1}$ azadirachtin) and NEEMIX ${ }^{\circledR} 4.5$ (47.6 g i.a. L-1 azadirachtin) and the insecticides approved for their use are pyrethrum, rotenone, nicotine, garlic and capsicum extract and powder the mixture of neem leaf and seed (Grain Protector $^{\circledR}$, Mexican Fitorganic) (Isman, 2006).

In Mexico, Ultraquimia Group S.A. de C.V., manufactures organic and agrochemicals products used in the control of plant health problems and carry out coordinated studies with researchers from the National Research Institute Forestry, Agriculture and Livestock (INIFAP) to determine the biological effectiveness of botanical insecticides produced, such as BIODI ${ }^{\circledR e}$, PROGRANIC ${ }^{\circledR}$ CinnAcar and PROGRANIC ${ }^{\circledR}$ Nimicide 80 among others, recommended for control of Diaforina (Diaphorina citri), mealybug (Planococcus citri), whitefly (Bemisia tabaci, Trialeurodes vaporariorum), aphids diver (Paratrioza cockerelli), bold (Phyllocoptruta oleivora), asian citrus psyllid (Diaphorina citri), diamond back moth (Plutella xylostella), worm looper (Trichoplusia ni), thrips (Thrips spp., Frankliniella spp., Caliothrips phaseoli, Heliothrips sp.) and aphids (Aphis spp, Myzus persicae, Brevicoryne brassicae, Toxoptera spp.).

Isman (1999) indicated that within 10 to 15 years, specifically the botanical insecticides probably represent about $50 \%$ of the total insecticide market. However, the current availability of biopesticides market comprises a small portion of the total volume of pesticides available. According to FAO data, world consumption of bioinsecticides for 2009 represented $0.2 \%$ of the total consumption of insecticides (FAO, 2009). Nevertheless, these products remain important in the insect pest management for the reasons mentioned above.

FAO (1999) indicated that little information exist about the use of botanical pesticide on the crop protection or stored food, also have been few evaluation of the effectiveness of these materials under real conditions of use on field. Currently plant species more recognized and evaluated under laboratory conditions belong to the genus Azadirachta, Piper, Chenopodium, Ipomoea, Mentha, Annona, and Tanacetum. However, the use of most of these plants has not been divulged due to lack of appropriate programs and properly established of outreach and training. Multinational corporations in western Mexico are implementing alternative 
pest management in tobacco-growing areas, to try to reduce the amount of synthetic pesticides used; in this sense, botanists become an effective and attractive alternative (Isman, 2008). Several traditionally used plant preparations have found local commercial markets, for example Ryania speciosa (Ryania) (Flacourtiaceae) which contains an insecticidal alkaloid, and Haplophyton spp. (Apocynaceae) have been used in the West Indies and Mexico for crop protection (FAO, 1999), situation depicted a growing and progressive interest in the use of this alternative in pest management, however the situation is confused, because sometimes ambiguous recommendations are made about the local use of these products without having been previously validated by field investigations and biosecurity. In Mexico and throughout Latin America, this is common, and is manifested in the publication of manuals that describe and encourage the use of botanical pesticides, which usually collect basis of partial observations and reviews established by the people that have empirically determined the effectiveness of certain plants and their formulated in the pest management.

Undoubtedly, it is not strange that in the short term register new plants and compounds with potential usefulness pesticide or plaguistatic with novel modes and sites of action to ensure their gradual distinctiveness in the market and enabling to increase the range of lowrisk alternatives for pest management.

\section{Modes and sites of action}

In the current development of botanical insecticides has increased interest in the characterization of the active compounds. Secondary metabolites of plants with insecticidal or insectistatic properties cause alterations in biochemical and physiological insects (hormonal, neurological, nutritional or enzymatic) when operating with repellent, antifeedant, growth regulation, oviposition deterrent and lethal toxicity, among other activities (Isman, 2006; Singh \& Saratchandra, 2005).

Different modes of action are described for many active compounds, for example, when are applied on the crop to be protected, they can act systemically in the plant by penetrating through the stomata and transported through the vascular system, altering its enzymatic complex, transpiration and changes in the composition of sap; other phytocompounds increase plant's energy, promote the synthesis of sucrose to help strengthen your metabolism and immune defense system. In many cases induce repellency and excitement of the nervous system from insect pests hindering the flight and oviposition therefore decrease the populations of insect pests.

The mechanism of action and target sites of the active phytochemicals on insects is diverse. Some cause effects by contact or ingestion being generally difficult their detoxification. The extracts or phytocompounds that acting through contact can penetrate and dissolve the lipoprotein matrix of the cuticle and cell membranes of insects destroying the exoskeleton, disrupting permeability and cellular physiology, causing dehydration and consequently death or reduce the oxygen consumption of nymphs, larvae and adults killing them by asphyxiation, affect the peripheral and central nervous system causing hyperexcitation, hypersensitivity, to external stimuli, seizure, muscle tetanization, effect protein synthesis and cell membranes, causing further death. The hyperexcitation of the nervous system also cause the masking of pheromones responsible for the mating process. The phytochemicals that acting by ingestion alter the physiological rhythm of the digestive system, preventing the contraction of the muscles of the intestine, causing his paralysis and hemolysis. There 
are components that act as repellents to block and inhibit the ability to search and locate food (antifeedant effect) reducing the amounts ingested and increased parasitism and predation by staying longer exposed to the environment and weak; repellency may be regarding the use of systems of chemical interaction between plant-insect chemical; the alomones, that plants synthesize when interacting with individuals of another species (insect pests, for example) induce them respond with physiological change or behavioral modifying which favors only the plant. The mechanism by which the repellent activity occurs could also be due to a mixed action for an unpleasant effect on the sensory endings as well as a chemical blocking of the perception that insect use for guidance.

The phytochemicals that cause lethal toxicity against insects larvae affect on any of the following target sites: midgut epithelium, gastric caeca, malpighian tubules, and in the nerve axon because disruption of channel sodium whose result in the insect is hyperactivity and seizure. The mechanism of action involves disruption of metabolism both through inhibiting the transport of electrons and uncoupling the ATP transport system, depolarization of the membrane potential, effect on calcium channel with sustained muscle contraction and inhibition of acetylcholinesterase (Shaalan et al., 2005; Weinzierl, 2000). Other phytocompounds asset, have a high effect of "knockdown", causing that the insect to stop feeding, become paralyzed and die of starvation soon after being in contact with the product or treated surfaces.

In experimental tests with sublethal concentrations of the extracts or active compounds of plants, there is often an extension of the period of biological development of the insects under study, making it possible to determine the characteristics effects of botanical extracts classified as regulator of growth, which contain phytoecdysones, phytojuvenoids and juvenile hormone causing prolongation of the stages of development, affecting the size, adult emergence, the physiology of reproduction by disrupting the reproductive system, fertility and hatching of larvae, resulting in effective control (Shaalan et al., 2005). The effect of phytochemicals that cause growth inhibition in various stages of development of insect pests act through inhibiting larval and pupal molt, longer duration of larval and pupal stage, morphological abnormalities and mortality during the molt among other effects (Shaalan et al., 2005).

Morphological abnormalities are observed in different development stage of insect, such as damage in the process of melanization in larvae and pupae, death in the intermediate stage of a larva and pupa (in this case can be observed organisms with the head of a pupa and the abdomen of a larva), death of adults with wings caught in the pupal exuviae and adult difficulties to fully emerge (Shaalan et al., 2005), these anomalies indicate an inhibitor effect on metamorphosis, probably due to disruption of hormonal control, and interference in the synthesis of chitin during the molting process (Pushpalatha \& Muthukrishnan, 1999; Saxena \& Sumithra, 1985). In the embryonic stage usually observe dehydration on eggs, bleeding, and death of embryo.

The biological effects of the phytocompound mentioned above are manifested individually or in combination depending of the chemical enrichment of plant species with potential pesticide and interactions that exists between the compounds. Many of the botanicals products that exhibit combined effects, such as the simultaneous damage in the larval development time and adult emergence, occasionally extend to the progeny of the larvae exposed to these treatments (Shaalan et al., 2005).

Boeke et al. (2004), validated the toxic and repellent effect of 33 plants used in Africa since the antique of empirical and traditional manner, for beetle Callosobruchus maculatus control. 
The laboratory evaluation showed that the powders of Nicotiana tabacum, Tephrosia vogelii, and Securidaca longepedunculata significantly reduced the number of beetle progeny and the species Clausena anisata, Dracaena arborea, T. vogelii, Momordica charantia y Blumea aurita had repellent activity, as reported experimentally that the majority of species assessed, provided effective control against $C$. maculatus.

Certain compounds are well known for their mechanisms of action, as quassin, a triterpene isolated from the wood of Quassia amara (Simaroubaceae). The quassin is an insecticide that show effects on the mosquito larval Culex quinquefasciatus through the inhibition of tyrosinase enzyme activity and consequently alter the development of the cuticle (Evans \& Raj, 1991). This compound has also been tested successfully in cereal crops to control aphids (Sengonca \& Brüggen 1991) by the mechanism of inhibition of enzymes of the insect.

Species of the family Meliaceae are source of azadarachtin, a limonoid marketed and appreciated by their biological activities pesticides, such as the antifeedant effect, the regulation of growth, as ovicidal and larvicidal, among others. The main effect of azadirachtin is to inhibit development, especially affecting the molt, by inhibiting the hormone ecdysone. Scott et al. (1999), showed that azadirachtin caused inhibition of voltaje $\mathrm{K}^{+}$channel in cultured rat neurons, this compounds has also shows antimitotic affect on Sfg insect cell line, resulting in prolongation of repolarization (Salehzadeh et al., 2003). Microscopic studies have indicated that azadirachtin interfere with the formation of the mitotic spindles and in the assembly of microtubules in the axoneme during microgametogenesis of Plasmodium berghei (Billker et al., 2002).

The family Piperaceae has been used as sources of pesticides to contain piperamides, several lignans, and derivates of benzoic acid. The piperamides, are molecules with dual biological activity, the amide group is neurotoxic and secondly the group methylenedioxyphenyl (MPD) is an inhibitor of cytochrome P450 in the insect pest, which participates in the metabolism of fatty acids and steroids (Scott et al., 2003).

Commercial botanical insecticide, rhodojaponin-III, islated from Rhododendron molle effect on more than 40 species of insect pests being antifeedant, oviposition, ovicidal, inhibitor of growth and change and toxic by ingestion and through contact. Previous studies indicate that this compound inhibits proliferation of $S f 9$ insect cell (isolated from pupal ovariantissue of Spodoptera frugiperda) dose-dependent effect. Besides interfering with cell division, the concentration of $\left[\mathrm{Ca}^{2+}\right]$, and intracelular $\mathrm{pH}$ (Cheng et al., 2011).

\section{Pesticide compounds}

Plant extracts and their derivatives are a source of many chemical compounds with potential insecticide or insectistatic and processed forms of botanical insecticides are isolated and purified compounds through extractions and distillation. For instance, nicotine and limonoid are distilled from plant extracts (Weinzierl, 2000).

Plants produce a vast and diverse reserve of secondary metabolites actives on different animals and plants of other species, allowing them to maintain relations of cohabitation (attractants) or defense (toxic or repellent substances) (Kutchan \& Dixon, 2005). These secondary metabolites are not essential for growth and development of plants, but they are required for interaction with the environment and to respond to pressures such as scarcity of water and nutrients, extreme temperatures, to deter to the herbivores microorganisms 
and viruses; also serve as signals to communicate with other organisms (Felton et al., 2008; Wink \& Schimmer, 1999).

The demand dynamic of biotic and abiotic environment gives the natural plasticity to the secondary metabolism and encourages the evolution of genetic diversification of the plant and thus generating a abundant group of natural products with variety of chemical structures (Kutchan \& Dixon, 2005) many case bioactive (Macías et al., 2007).

The biosynthesis of secondary metabolites and storage of these compounds is regulated in space and time, so the growing tissues are more vulnerable and more protected than the old or senescent tissues. For instance, is usually observed in seeds, latent and period of germination, flower buds and young tissues retain a certain amount of specific compounds or are actively synthesized. The organs that are important for the survival and multiplication, such as flowers, fruits and seeds, are almost always a rich source of chemical defenses (Wink, 1999). In addition, the metabolic profile usually varies between parts of a plant, including developmental stages, sometime during the day, the geographic location of the plant species and between plant species (Wink, 1999).

Many secondary metabolites have biological activities such as insecticides, fungicides, and phytotoxic properties that can be employed in agriculture (Wink, 1999) either alone or in combination with other chemical and biological (Trysyono \& Whalon, 1999; Weinzierl, 2000). Particularly during the past 20 years, phytocompounds such as terpenes, alkaloids, rotenone and pyrethrum have gained commercial importance for the development of botanical insecticides (Isman, 2006).

Macías et al. (2007), mention that it was until the twentieth century when the study of plant compounds and their mechanism of action is made relevant. The development of spectroscopic technique allowed the isolation and identification of pure active compounds such as (5E)-ocimenone from Tagetes minuta (1978), rotenone from Derris elliptica (1983), azadirachtin from Azadirachta indica (1981), capillin from Artemisia nilagirica (1990), quassin from Quassia amara (1991), neolignans from Piper decurrens (1996), arborine, a new bioactive compound related to quinazolone alkaloid, from Glycosmis pentaphylla (1999) and goniothalamin From Bryonopsis laciniosa (2003) (Shaalan et al., 2005).

Kathuria and Kaushik (2005), determinedthe antifeedant effect of etanol extracts of leaves from Eucaliptus camaldulensis y Tylophora indica en Helicoverpa armigera (Hûbner) and found that the alkaloids identified in T. indica are responsible for this activity. In another study, extracts were evalued red maple (Arce rubrum) resulting assets over Malacosama disstria larvae, causing antifeedant affect. Gallates derivatives (1-O-galatoil-L-ramnosa) present in the plant were compounds responsible for this activity (Zaid \& Nozzolillo, 2000).

\section{Mexican medicinal plants}

According to estimates published up to now, Mexico is the third country worldwide with a diversity of vascular plants. Of the 250000 species located around the world, in the Mexico there are $22411(10 \%)$, not including nearly a thousand species (Villaseñor \& Magaña, 2002; Vovides et al., 2010). Diversification, is back to geological times and have been possible by the variety of soil conditions, climate and topography of the country, as well as plant genetics and anthropogenic activities of conservation, introduction, selection and plant breeding. 
In general terms, the biological, ecological and cultural diversity of Mexico has led to the generation of empirical and scientific knowledge, the first has its origins in ancient times with the practices of observation to the nature and experimentation through trial and error, inheritance transmitted from generation to generation through texts or stories. Through the inventory made under the empirical system made were possible the first classifications of plants with data on their ecology, biological importance and usefulness (Gómez-Pompa, 2010). In Mexico the codices written by important pre-Hispanic groups are transcendental. With regard to the Azteca codex De la Cruz-Badiano is a record conceptual and illustrative of the medicinal plants used in New Spain of the Sixteenth Century, regarded worldwide as one of the best collections of Mexican folk medicine, this wealth of literature has fractured and disrupted on several occasions, however, has been rescued, preserved and expanded by the country's ethnic groups and has now increased interest to validate through experimental science (Bye \& Linares, 1999). Scientists from Mexico and other countries have used the codices, herbal, picked and general ethnobotanical practices for various purposes, among these, botanists have been interested in reviewing corroborated and enrich the etnoflora catalogs, describing the location, uses regional and popular names of plants and the phytochemical have used ethnobotanical studies as a reference for the location of plants with biological significance and the search for new phytocompounds useful in protecting, and preserving food un pre- and post-harvest either as pesticides and botanical repellents, as well as raw materials for pharmaceutical, cosmetic, chemical, beverage, food and bioprocesses. A current record, provides that Mexico has about 7000 species of vascular plants with some use for various purposes (Caballero \& Cortés, 2001).

Importantly, there are still many regions of Mexico to explore thoroughly, to have an updated inventory of plants, a situation that reflects the potential in the many uses of these resources. In these sense, diversity and identification of endemic, native, and introduced strengthen several areas of research, local and foreign plant extracts or their derivatives. Of the plants with some kind of use, 3300 species have medicinal use (Pérez, 2001); in addition to its therapeutic properties, many of these plants have the potential to be used in the management of pests and phytopathogens of agricultural and livestock importance, ancient practice that originated with the beginning of agricultural activities. The global ecological problem that exists in modern times, mankind has created demand for residue-free agricultural products and alternatives to reduce agrochemicals use, so that the development of conservation and sustainable agriculture was necessary and this favors the development and commercialization of these botanical pesticides.

\section{Ethnobotanical study of Mexican medicinal plants with insecticide potential}

Traditionally, the plants located in each geographic region of Mexico, are used for different purposes. Many have multiple applications and properties, the literature quotes are cite both for its medicinal properties as insecticides and antiparasitic properties. It is estimated that in Mexico there are about 7000 useful plant species, representing $31 \%$ of vascular plants located in the country (Caballero \& Cortés, 2001).

Ethnobotany is considered as a source for research of phytopesticides of interest to the agricultural and livestock with production sustainable and alternative.

This paper conducted a literature search and review of the publications on ethnobotanical studies in the country, plants that farmers and people in general routinely used to protect crops, stored grain, and ornamentals (Table 1). To confirm the medicinal use of plants 


\begin{tabular}{|c|c|c|c|c|c|c|c|}
\hline 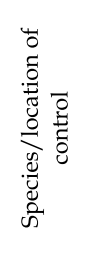 & & 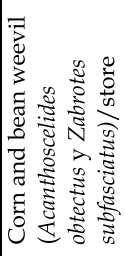 & 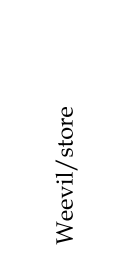 & & 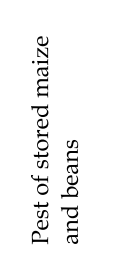 & & 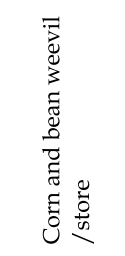 \\
\hline 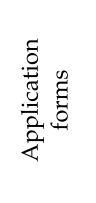 & & & 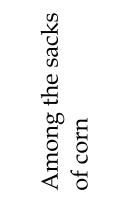 & & 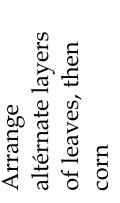 & & 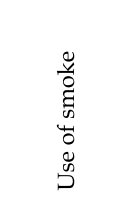 \\
\hline 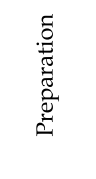 & & & $\sum_{0}^{\infty}$ & & 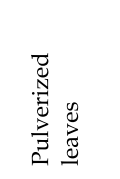 & & 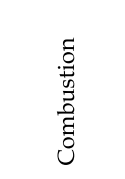 \\
\hline 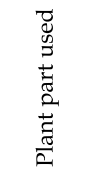 & & & $\begin{array}{l}\frac{\vec{\pi}}{\sigma} \\
\frac{\pi}{2} \\
\frac{0}{0} \\
\frac{0}{3} \\
3\end{array}$ & & 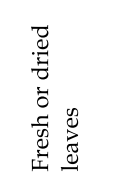 & & $\begin{array}{l}\tilde{\Xi} \\
\stackrel{W}{ }\end{array}$ \\
\hline 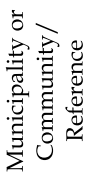 & & 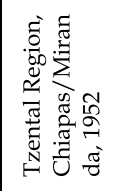 & 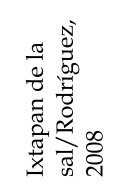 & & 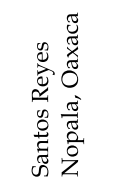 & & 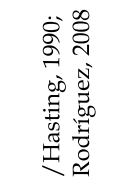 \\
\hline 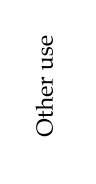 & & 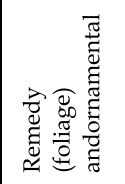 & 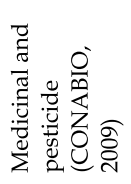 & & 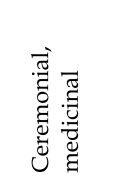 & & 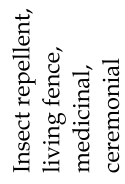 \\
\hline 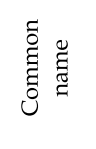 & & 䒕 & 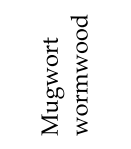 & & $\frac{\vec{v}}{\vec{d}}$ & & 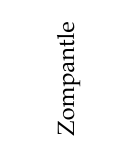 \\
\hline 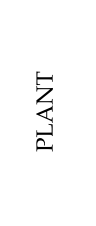 & 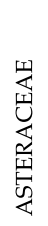 & 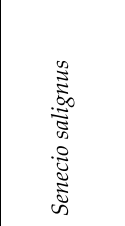 & 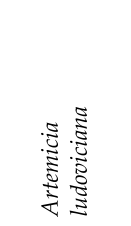 & 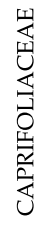 & 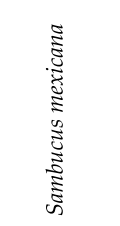 & 窸 & 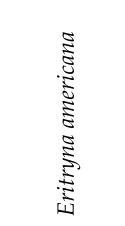 \\
\hline
\end{tabular}

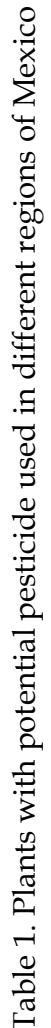




\begin{tabular}{|c|c|c|c|c|c|}
\hline PLANT & $\begin{array}{c}\text { Common } \\
\text { name }\end{array}$ & Other use & $\begin{array}{l}\text { Municipality or } \\
\text { Community/ } \\
\text { Reference }\end{array}$ & $\begin{array}{c}\text { Plant } \\
\text { part } \\
\text { used }\end{array}$ & Preparation \\
\hline MELIACEAE & & & & & \\
\hline Cedrela spp. & & $\begin{array}{l}\text { Timber } \\
\text { Medicinal }\end{array}$ & $\begin{array}{l}\text { Cuetzálan, Puebla y } \\
\text { Chicontepec, } \\
\text { Veracruz/ } \\
\text { Rodríguez, } 2008\end{array}$ & $\begin{array}{l}\text { Leaves } \\
\text { and seed }\end{array}$ & Dust \\
\hline Melia azedarach & $\begin{array}{l}\text { Tree of } \\
\text { Paradise }\end{array}$ & Medicinal & $\begin{array}{l}\text { Martínez de la } \\
\text { torre, Veracruz/ } \\
\text { Rodríguez } 2008\end{array}$ & $\begin{array}{l}\text { Dried } \\
\text { leaves }\end{array}$ & Dust \\
\hline Trichilia havanensis & Xopiltetl & & $\begin{array}{l}\text { Tuzamapan de } \\
\text { Galeana, } \\
\text { Puebla/Rodríguez, } \\
\text { 2008; López- } \\
\text { Olguín, } 1997\end{array}$ & $\begin{array}{l}\text { Leaves } \\
\text { and fruit }\end{array}$ & Dust \\
\hline PIPERACEAE & & & & & \\
\hline \multirow[b]{2}{*}{ Piper auritum Kunth } & \multirow[b]{2}{*}{$\begin{array}{l}\text { Mumo, } \\
\text { yerba santa }\end{array}$} & \multirow[b]{2}{*}{ Medicinal } & $\begin{array}{l}\text { Chatino territory, } \\
\text { Oaxaca/ Miranda, } \\
1952\end{array}$ & $\begin{array}{l}\text { Whole } \\
\text { plant }\end{array}$ & Dried and ground \\
\hline & & & $\begin{array}{l}\text { Tepetate, } \\
\text { Veracruz/ Ortega } \\
\text { \& Rodríguez, } 1991\end{array}$ & $\begin{array}{l}\text { Whole } \\
\text { plant }\end{array}$ & Powdery \\
\hline
\end{tabular}

Table 1. Plants with potential pesticide used in different regions of Mexico 


\begin{tabular}{|c|c|c|c|c|c|}
\hline 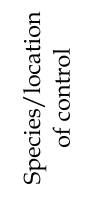 & & & 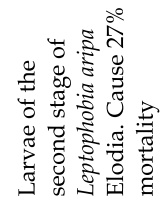 & & $\begin{array}{l}0 \\
\vdots \\
3\end{array}$ \\
\hline 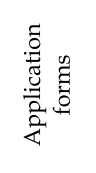 & 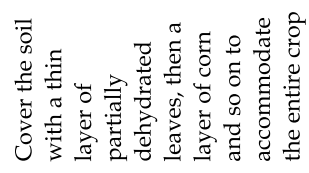 & & 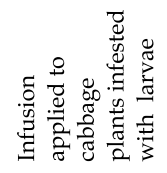 & & \\
\hline 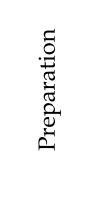 & 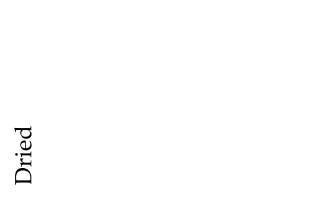 & & 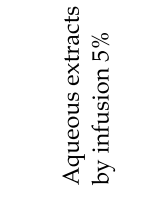 & & \\
\hline 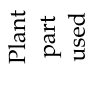 & 总 & & 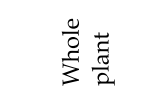 & & \\
\hline 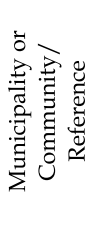 & 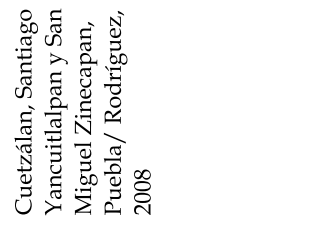 & & 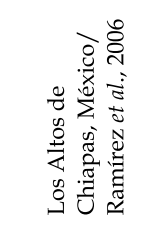 & & 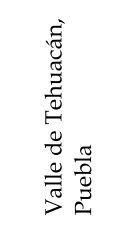 \\
\hline 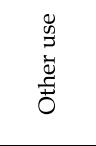 & 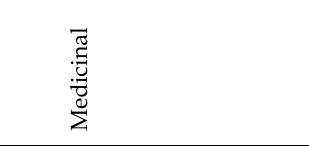 & & 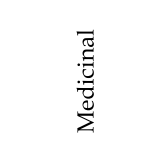 & & 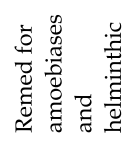 \\
\hline 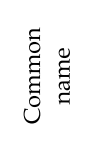 & 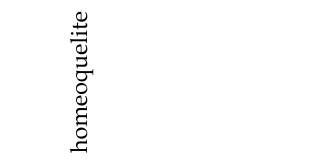 & & & & 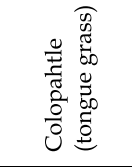 \\
\hline$\sum_{3}$ & 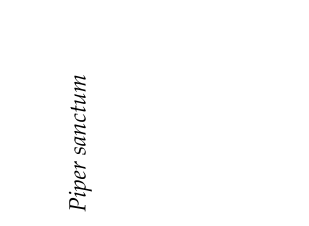 & 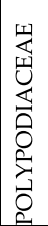 & 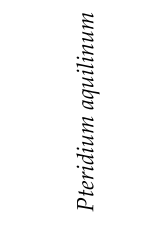 & 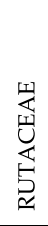 & 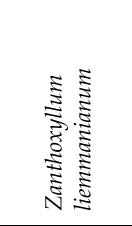 \\
\hline
\end{tabular}

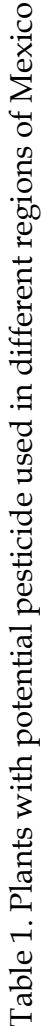




\begin{tabular}{|c|c|c|c|c|c|}
\hline PLANT & $\begin{array}{l}\text { Common } \\
\text { name }\end{array}$ & Other use & $\begin{array}{c}\text { Municipality or } \\
\text { Community/ } \\
\text { Reference }\end{array}$ & $\begin{array}{l}\text { Plant } \\
\text { part } \\
\text { used }\end{array}$ & Preparation \\
\hline \multicolumn{6}{|l|}{ SAPINDACEAE } \\
\hline Dondonaea viscosa & & & $\begin{array}{l}\text { / Lagunes et al., } \\
1984\end{array}$ & & \\
\hline \multicolumn{6}{|l|}{ SMILACEAE } \\
\hline \multirow{3}{*}{ Smilax aristolochiaefolia } & \multirow{3}{*}{ Sarsaparrilla } & \multirow{3}{*}{ Medicinal } & / Martinez, 1983 & & \\
\hline & & & & & \\
\hline & & & $\begin{array}{l}\text { / Lagunes et al., } \\
1984\end{array}$ & $\begin{array}{l}\text { Whole } \\
\text { plant }\end{array}$ & Maceration \\
\hline S. morarense & sarsaparrilla & Medicinal & / Martinez, 1983 & & \\
\hline
\end{tabular}

Table 1. Plants with potential pesticide used in different regions of Mexico 


\begin{tabular}{|c|c|c|c|c|c|}
\hline 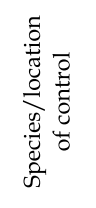 & 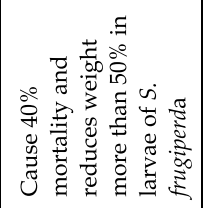 & & 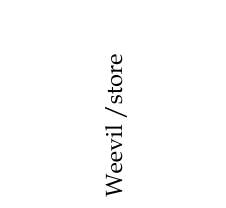 & 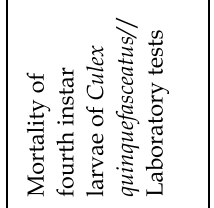 & 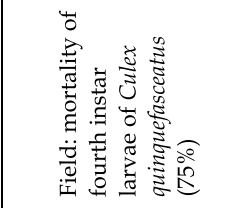 \\
\hline 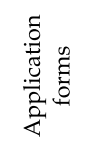 & & & 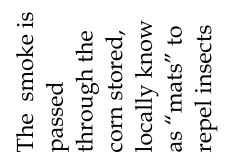 & & 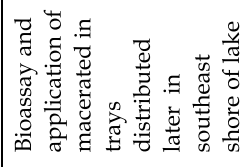 \\
\hline 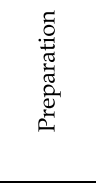 & 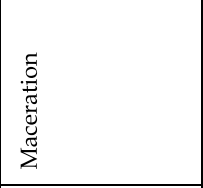 & & 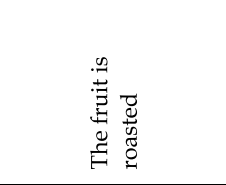 & 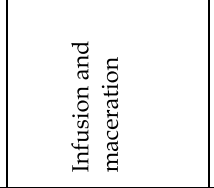 & 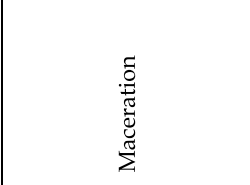 \\
\hline 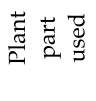 & $\begin{array}{l}\frac{0}{0} \\
\frac{0}{3} \frac{\pi}{2}\end{array}$ & & 总节 & 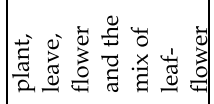 & $\stackrel{\Xi}{\Xi}$ \\
\hline 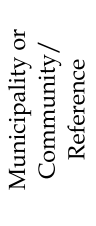 & 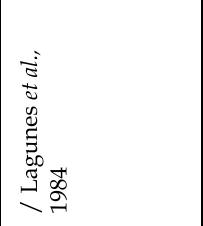 & & 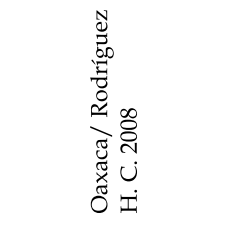 & 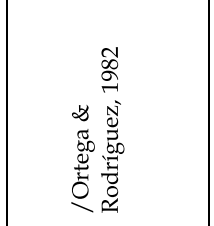 & 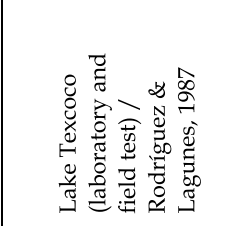 \\
\hline 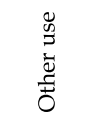 & 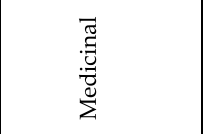 & & 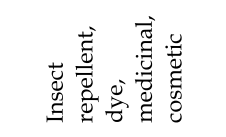 & & 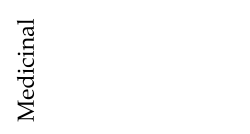 \\
\hline 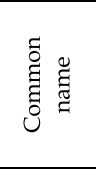 & 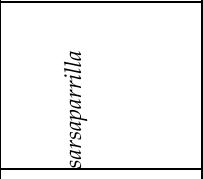 & & ฮี & & 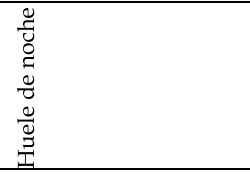 \\
\hline 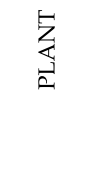 & 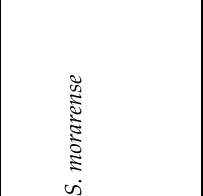 & 穻 & $\begin{array}{l}\text { के } \\
\text { के } \\
\text { 竝 } \\
\text { 离 } \\
\text { है }\end{array}$ & & 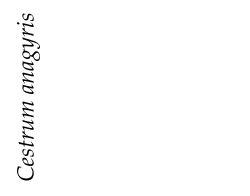 \\
\hline
\end{tabular}

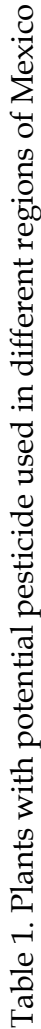




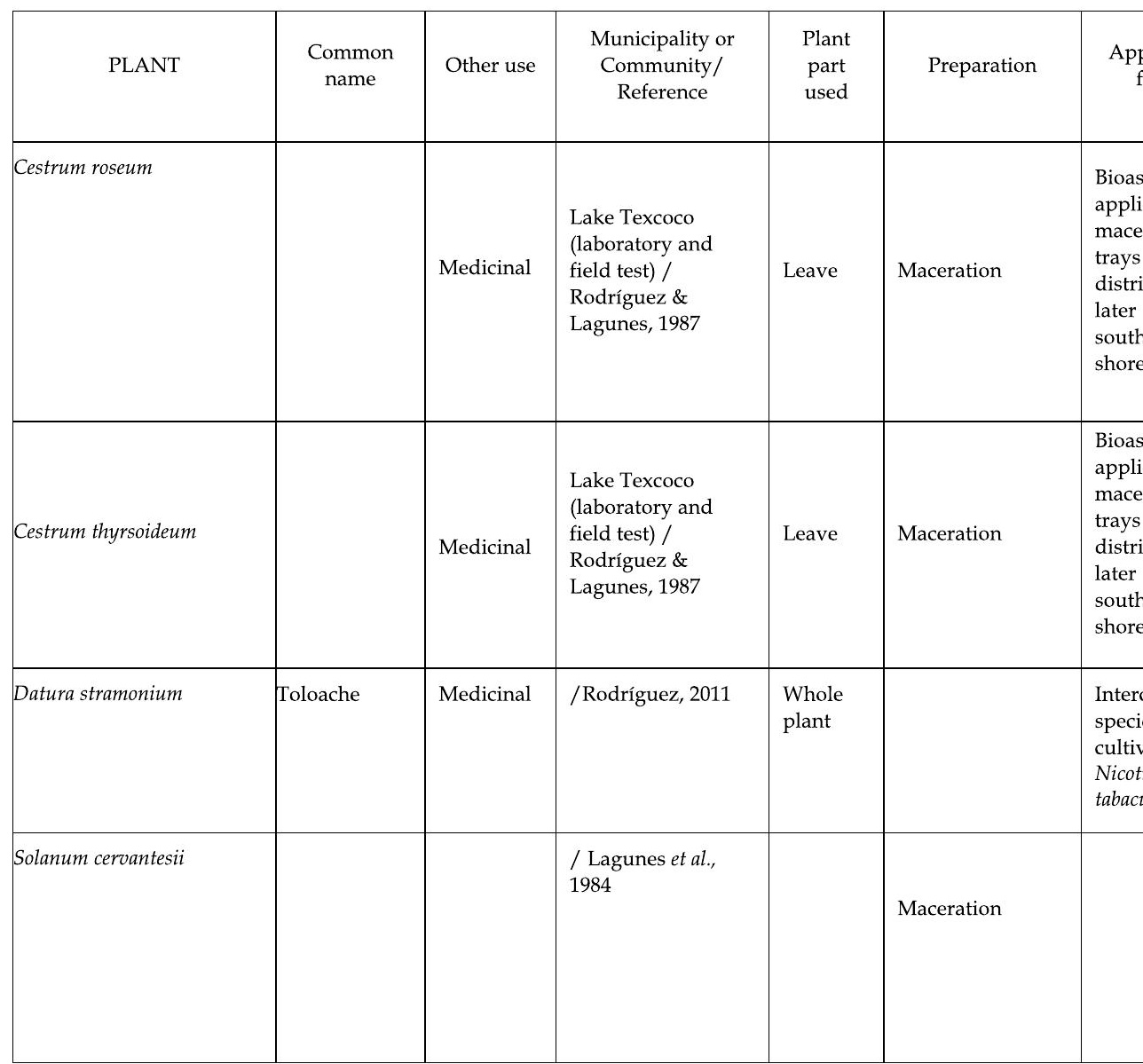

Table 1. Plants with potential pesticide used in different regions of Mexico 


\begin{tabular}{|c|c|c|c|c|c|c|}
\hline 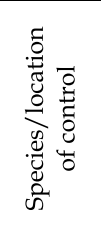 & & 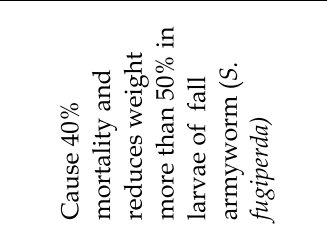 & & 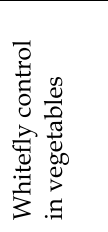 & & 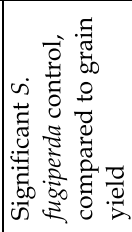 \\
\hline 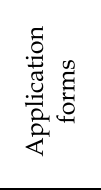 & & & & & & 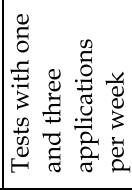 \\
\hline 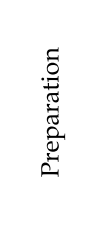 & & 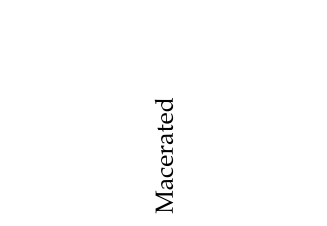 & & 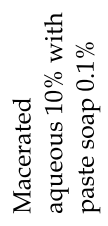 & & 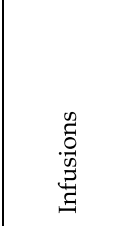 \\
\hline 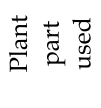 & & 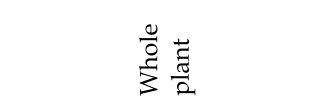 & & 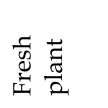 & & \\
\hline 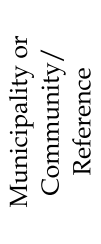 & & 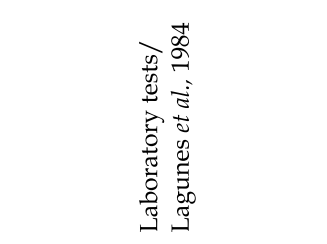 & & 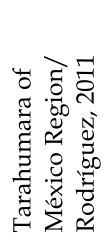 & & 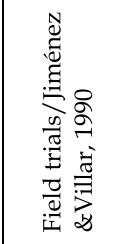 \\
\hline 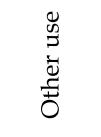 & & 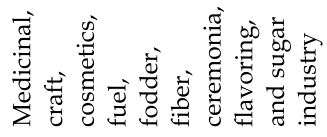 & & 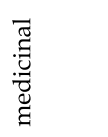 & & \\
\hline 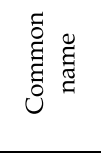 & & $\begin{array}{l}\frac{0}{0} \\
\frac{0}{2} \\
\frac{\pi}{\pi} \\
3\end{array}$ & & 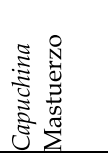 & & \\
\hline$\underset{3}{S}$ & 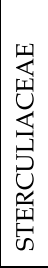 & 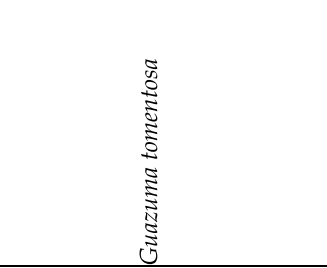 & 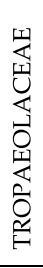 & 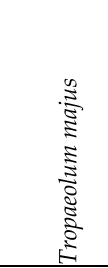 & 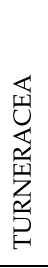 & 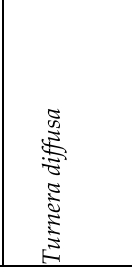 \\
\hline
\end{tabular}

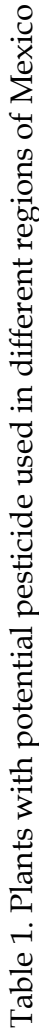


concerned are consulted databased of Plant Atlas of Traditional Mexican digital library of Mexican Traditional medicine of the National Autonomous University of Mexico with access at www.medicinatradicionalmexicana.unam.mx, as well as the book "The scientific investigation of the Mexican medicinal herbs" (Aguilar et al., 1993) and publications with information ethnobotany.

\section{Studies of insect pests of agricultural importance}

In Mexico and many parts of the world, people field for various decades have been consistently observed in their environment, and empirically they have selected plants that are not attacked by diseases and pests, many of which can be used as repellents and pesticides. Among the more promising botanical insecticides from the standpoint of its regulation, marketing and use, are products derived from plants that have already been validated by their pharmacological activity and insecticide, as the powdered of leaves and seed from neem (Grain Protector ${ }^{\circledR}$ ) and garlic extract (Biocrack ${ }^{\circledR}$ ) (Silva et al., 2002).

According to Dev and Koul (1997) worldwide about 2000 plant species have insecticidal active compounds with significant, mainly distributed in 61 families, of which we have identified for Mexico around 14 families of vascular plants by the number times cited in total publications consulted in this review, they are Asteraceae, Meliaceae, Convolvulaceae, Flacourtiaceae, Liliaceae, Solanaceae, Euphorbiaceae, Fabaceae, Lamiaceae, Rutaceae, Myrtaceae, Verbenaceae Burceraceae, Caricaceae (Table 2), despite diversity of resources with propierties worldwide, only a few of these species have commercial value in the market phytoinsecticides. Some authors like Isman (2006) mention that in modern times should restructure the search for new species with insecticidal or insectistatic activity and concentrate on the validation, regulation and marketing of phytoinsecticides already known for their potential. In developing countries like Mexico, is possible that the search of species with potential for pest control play an important role in food production (agricultural and livestock) and public health and livestock, because of empirical and traditional in several regions have been using some native species with this potential, either in the form of hedges, crude extracts, combustion products, powders, resins, latex, sap, poison baits or live plants interspersed throughout the orchards.

Although Mexico exist isolated investigations on the search for plants with insecticidal activity (in some case having as antecedent pharmacological activity), there are well established research groups from different institutions of the country, for several years, have established this area as its research. A clear example is found in the Postgraduate College (Montecillo, Texcoco, State of Mexico) where Dr. Cesáreo Rodríguez Hernández, Dr. Laura D. Ortega Arenas and the group of contributors, since 1981 have worked consistently for the validation of plans that have traditionally been used since ancient times in rural communities across the country. About 30 rears, Dr. Rodríguez has collected and documented information from various parts of the country about the type local vegetation, plants with properties, uses, controlling pest species and forms of preparation. Generally, the information is recorded as prescription practices used among rural workers, agricultural technicians and promoters of organic farming, which details the use of local flora for the preparation of powders, baits or extracts, using materials available in the field. These research ranging from the intensive search for potential plant species present in a community insecticide and conducting toxicity tests on one or more species of insect pests of 
worldwide importance such as Spodoptera frugiperda and the complex of while fly, or a local impact, such as Leptophobia aripa elodea (Table 3). The evaluations have been conducted in species of insect pests warehouse, public health and agricultural, using different parts of the candidate plants for preparations carrying out tests in laboratory and field level in several states. The information that Dr. Rodríguez and other working groups with whom he has worked, is recorded in different memories of the event "national and international symposium on plant and mineral substance in pest control" performed periodically in Mexico and is also published in scientific journals.

In this sense, Villavicencio-Nieto and colleagues (2010), have determined that the State of Hidalgo there is much dependence on farmers for the local flora, the Autonomous University of Hidalgo State investigated the traditional use of 124 species of plants in the region, specifically for the pest control, only 97 of them being medicinal and 11 are used as insecticides. This research found that these plants have different uses in other regions of Mexico, including pharmacologic, as is the case Galphimia glauca, which have been used all its parts in different products (extracts, powders, essencial oils and resins) used in the management of pests of livestock agriculture, and health, such as human lice. Plant species most used in the communities of Hidalgo were Trichilia havanensis, Psidium guajava, Nicotiana tabacum, Tagetes erecta, Mentha rotundifolia, Ipomoea stans, Tagetes lucida, Parthenium hysterophorus, and Schinus molle. As a result of surveys conducted in this investigation, Villavicencio-Nieto and colleagues found that the plants with insecticide potential under study, are used to control 29 different pest species such as lice, fleas, weevils, ants, mosquitoes, cockroaches, among others, and are toxic to vertebrates such as dogs, squirrels, rats, snakes, and raccoons. This marks the importance of promoting the proper use of botanicals among communities.

At the Center of Development of Biotic Products (CEPROBI) National Polytechnic Institute, Dr. Camino Lavín, developed his research on finding alternatives to the use of synthetic pesticides and in 1985 founded the department of plant-insect interactions, which among other line, encourages the development of phytoinsecticides. Currently, this line of research continues the group of collaborators and has evaluated Ficus goldmanii, Ficus petiolaris (Moraceae), Cochlospermun vitifolium (Bixaceae), Croton ciliatoglanduliferus (Euphorbiaceae), Crescentia alata (Bignoniaceae), Phitecellobium dulce, species of the genus Tagetes (Asteraceae) and also species in the Sierra Huautla, at the State of Morelos, as Prosopis laevigata (Fabaceae) and species of the genus Bursera (Burseraceae) and Lupinus (Fabaceae), which is known that several species have compounds with insecticidal and medicinal activity. They have also evaluated the biological activity of seeds of different varieties of Carica papaya (Caricaceae), which present effect insecticide e insectistatic against Spodoptera frugiperda (Franco et al., 2006).

In the Autonomous University of San Luis Potosi, have been assessed by laboratory tests, powdered of leaves and flowers from 81 plant species belonging to the Asteraceae family, the selection was made considering that this family includes many species with insecticidal activity or deterrent and also because they have pharmacological activities, the evaluations were conducted on Sitophilus zeamais. Of the 169 powder tested 50 were promising, highlighting the powder of leaves from Zinnia acerosa and Z. peruviana, in terms of insectistatic activity highlighted Bahia absintifolia, Stevia pilosa and Jefea brevifolia (JuárezFlores et al., 2010). 
Trichilia havanensis (Meliaceae) is a species found from southern Tamaulipas to Tabasco and Chiapas, in considered native to Mexico and given its relationship with Azadirachta indica and Melia azaderach belonging to the same family, has been studied for over 15 years in the Benemerita Autonomous University of Puebla. The assessments are aimed at finding alternatives to control Ceratitis capitata, fruit pest species with cosmopolitan distribution and quarantine regulations in several countries, his control is restricted to the use of insecticidal organophosphates and pyrethroids. Other insects that have been used for the evaluations are Spodoptera exigua, especies del género Phyllophaga, Leptinotarsa decemlineata, Thrips tabaci, Helicoverpa armígera, Spodoptera litorali and Hypotenemus hampei. Actually, after years of experimentation and validation is likely to be patented and marketed a bioinsecticide obtained from the fruit species (López-Olguin et al., 1997; López-Olguin et al., 1998; LópezOlguin et al., 2002).

The National Autonomous University of Mexico there is also consolidated groups of researchers in this area. The Department of Naural Products Chemistry Institute have among their line of validation of natural products with antifeedant and insecticidal activity, particularly plant species of the Labiatae, Burseraceae and Verbenaceae family. Have evaluated the activity of the purified active compounds are present in species such as Vitex hemsleyi. The tests were done in neonate larvae of S. frugiperda (Villegas et al., 2009). In the Faculty of Sciences, is studying the antifeedant activity of plant extracts from Acacia cornigera, Bursera species and some species of Solanaceae, the evaluations are performed on neonate larvae of $S$. frugiperda, and is also looking for alternatives to control Boophilus microplus.

Northern Sierra of Oaxaca, community groups have received government support for production to tomatoes and other vegetables, have been advised by engineers and technician from the Institute of Technology in the Oaxaca Valley, the presence of whiteflies in the crop has been controlled with the use of extracts and infusions of garlic, onions, marigolds, basil, pepper, rue, chamomile, and others, the advantages are clear as reduces the investment cost and the food product developed under the organic system can be sold at higher prices.

In the highlands of Chiapas cultivation of cabbage (Brassica oleracea) is of economic importance are usually affected mainly by the cabbage worm Leptophobia aripa elodia to control in these communities have used synthetic pesticides, to reduce costs, health problems and pollutation, El Colegio de la Frontera Sur has sought alternative biological control. This region has recorded around 1650 medicinal plant species, however, there are no studies on the effect of extracts of these species at different developmental stage of $L$. aripa elodia, a situation that prompted the selection of 15 wild species of insecticidal activity history ethnobotanical and medicinal use. The results showed no significant activity on $L$. aripa elodia although some of the species tested showed activity against Locussta migratoria and Trichoplusia ni, therefore should continue investigating the potential of these species in pest management (Ramírez-Moreno, et al., 2001). There has also been collecting traditional knowledge of indigenous Tzeltal farmers of Chiapas highlands, on the management of agricultural pests (ants, Phyllophaga spp., S. frugiperda, Doru taeniatum, Diphaulaca wagnerii y L. Aripa elodia) four of the most common crops in the region, this led to the evaluation of the sensitivity of these pest species and 64 medicinal wild plants belonging to the basic list of 
useful plants from this ethnic group, the idea to promote local and regional control ecological these pests (Trujillo-Vázquez \& García-Barrios, 2001).

In the Biological Control Laboratory, Biotechnology Research Center, of the Autonomous University of Morelos State (UAEM), for 15 years under the initial coordination of Dr. Eduardo Aranda Escobar ${ }^{+}$, we have developed the research of plant extracts with biological activity on insect pests. Most plants have been collected in the State of Morelos, many of which have pharmacological properties (Table 4). Among the species tested include the genus Ipomoea (Convolvulaceae) bioassays have been done on S. frugiperda y Bemisia tabaci at different stages and we have observed different biological activities of the extracts, some Ipomoeas cause lethal toxicity against larvae and nymphs between 2-100\% mortality (I. carnea, I. pauciflora, I. intrapilosa, I. cuernavacensis, I. murucoides), others cause decrease in weight of the larvae of $S$. frugiperda between $90-15 \%$ reduction (I. murucoides, I. carnea e I. pauciflora) and others affect the life cycle (I. carnea: cause malformation of pupae and adult difficulty to emerge, I. pauciflora: prolonged pupal development time). We also conducted tests on the establishment in vitro of Ipomoeas with potential, as an option to develop biotechnological technique for various purposes; one is to optimize the use of phytocompounds responsible for biological activity on insect pests (Toledo, 2001; Aguirre, 2008; Gaona, 2009; Vera et al., 2009; Guzmán-Pantoja et al., 2010).

Although they are abundant records of plants with insecticidal potential, before recommending its use should be tested for biosafety and formulation, it is important to the safety of these products in non-target species and the health of domestic animals and humans. Although most species with a history of drug use in communities has an apparent safety backup, remember the legacy of Paracelsus (1567) "the dose makes the poison". Another factor to consider is the stock of plants because it could jeopardize the survival of these species in the ecological environment, in this regards is necessary to implement strategies for the compounds responsible for biological activity according to the phenological stage of the plant and seasonality is needed to establish the dates of collection and, if possible, establish community gardens for intensive planting of these plants with potential insecticide would have continuous availability of phytoinsecticides.

\section{References}

Aguilar C.A., Martínez A.M.A. (1993). Los herbarios medicinales de México. En: La investigación científica de la herbolaria medicinal mexicana. Secretaría de Salud (Ed.), México, pp. 89-102.

Aguirre, M.A. (2008). Actividad insecticida de tejidos callogénicos de Ipomoea murucoides (Roem. Et Schult) (Convolvulaceae), sobre Spodoptera frugiperda (Lepidoptera: Noctuidae). Tesis de maestría. Centro de Investigación en Biotecnología. Universidad Autónoma del Estado de Morelos. Cuernavaca, Morelos, México, 60 p.

Aldana, L.L., Hernández, R.M. \& Gutiérrez, O.M. (2007). Evaluación en vivero de extractos de tres especies de Lupinus sobre gusano cogollero Spodoptera frugiperda (Lepidoptera: Noctuidae). Procceding of X Congreso Internacional de Ciencias Agrícolas. Mexicali B. C., México. 
Aldana, L.L., Hernández, R. M. \& Gutiérrez, O.M. (2008). Efecto de polvos y extractos vegetales sobre Scyphophorus acupunctatus plaga del nardo y agave, Procceding of XI Congreso Internacional de Ciencias Agrícolas Mexicali, Baja California, México, 2008.

Aldana, L.L., Hernández, R.M. \& Gutiérrez, O.M. (2008). Efecto de Prosopis laevigata sobre Spodoptera frugiperda plaga del maíz. 2008. Procceding of VII Congreso Internacional, XIII Congreso nacional de Ciencias Ambientales. Cd. Obregón, Sonora, México, 2008.

Aldana, L.L., Salinas, S.D., Valdés, E.M., Gutiérrez, O. M. \& Valladares, C.M. (2010). Evaluación bioinsecticida de extractos de Bursera copallifera (D.C.) Bullock y Bursera grandifolia (Schltdl) Engl. en gusano cogollero Spodoptera frugiperda J.E. Smith (LEPIDOPTERA:NOCTUIDAE). Polibotánica, 29:149-158.

Ayala, O.J. (1985). Evaluación de sustancias vegetales contra el gusano cogollero del maíz Spodoptera frugiperda (J. E. Smith) (Lepidoptera: Noctuidae). Tesis de Maestría en Ciencias. Colegio de Posgraduados. Chapingo. México.

Billker, O., Shaw, M. K., Jones, I. W., Ley, S. V., Mordue A. J. \& Sinden R.E. (2002) Azadirachtin disrupts formation of organised microtubule arrays during microgametogenesis of Plasmodium berghei. Journal Eukaryotic Microbiology, 49 (6): 489-497.

Boeke, S., Baumgart, I., van Loon, A.J., van Huis, M., Dicke \& Kossou, D. (2004). Toxicity and repellence of African plants traditionally used for the protection of stored cowpea against Callosobruchus maculatus. Journal of Stored Products Research, 40(4):423-438.

Bye, R. \& Linares, E. (1999). Plantas medicinales del México prehispánico. In: Arqueología mexicana, Vol. VII, Núm. 39. México. pp. 4-13.

Caballero, J. \& Cortés, L. (2001). Percepción, uso y manejo tradicional de los vegetales en México. In: Rendón-Aguilar, B., Rebollar-Domínguez, S., Caballero-Nieto, J. y Martínez-Alfaro, M. A. (eds), Plantas, cultura y sociedad estudio sobre la relación entre seres humanos y plantas en los albores del siglo XXI, pp. 79-100. Universidad Autónoma Metropolitana-Iztapalapa y Secretaría del Medio Ambiente, Recursos Naturales y Pesca, pp. 315, ISBN: 970-654-782-7, México, D. F.

Camarillo, G., Ortega L., Serrato, M. \& Rodríguez, C. (2009). Actividad biológica de Tagetes filifolia (Asteraceae) en Trialeurodes vaporariorum (Hemiptera:Aleyrodidae). Revista Colombiana de Entomología 35(2):177-184

Carballo, M. \& Quiroga, R. (1986). Evaluación de extractos vegetales para el combate del gusano cogollero Spodoptera frugiperda (J. E. Smith) en villaflores, Chiapas. XXI Congreso Nacional de Entomología. Monterrey, Nuevo León, México, p. 134.

Céspedes, C., Calderón, J., Lina, L. \& Aranda, E. (2000). Growth inhibitory effects on fall armyworm Spodoptera frugeperda of some limonoids isolated from Cedrela spp. (Meliaceae). Journal Agricola Food Chemistry, 48:1903-1908.

Céspedes, C., Rodrigo, Salazar J., Martínez, M. \& Aranda, E. (2005). Insect growth regulatory effects of some extracts and sterols from Myrtillocactus geometrizans (Cactaceae) against Spodoptera frugiperda and Tenebrio molitor. Phytochemistry, 66:2481-2493.

CONABIO. (2009). Malezas de México. Heike, V. (ed.), retrieved from http://www.conabio.gob.mx.

Dayane, F.E., Cantrell, C.L. \& Duke, S.O. (2009). Natural products in crop protection. Bioorganic and Medicinal Chemistry, 17: 4022-4034. 
De la Torre, A. (2008). Agricultura sustentable en comunidades de la Sierra Norte de Oaxaca. Hernández M. (ed), In: Manual de capacitación para la participación comunitaria, pp. 31, México.

Dev, S. \& Koul, O. 1997. Insecticides of Natural Origin. Harwood Academic Publishers The Netherlands. pp. 365

Evans D.A., Raj R.K. (1991). Larvicidal efficacy of quassin against Culex quinquefasciatus. Indian Journal Medical Research, 93: 324-327.

Felton, G.W. \& Tumlinson, J.H. (2008). Plant-insect dialogs: complex interactions at the plant-insect interface. Current Opinion in Plant Biology, 11:457-463.

Franco, A.S., Jiménez, P.A., Luna, L.C. \& Figueroa, B.R. (2006). Efecto tóxico de semillas de cuatro variedades de Carica papaya (Caricaceae) en Spodoptera frugiperda (Lepidoptera:Noctuidae). Folia Entomológica Mexicana, 45(2): 171-177.

Gaona, H.M. (2009). Actividad biológicas de extractos de Ipomoea carnea (Jacq.) sobre Spodoptera frugiperda Smith (Lepidóptero: Nuctuidae). Tesis de Licenciatura en Biología. Facultad de Ciencias Biológicas. Universidad Autónoma del Estado de Morelos, México, pp. 140

García, A. J., Verde, S. M. \& Heredia, N. (2001). Traditional uses and scientific knowledge of medicinal plants from Mexico and Central America. Journal of herbs, Spices $\mathcal{E}$ Medicinal Plants, 8:37-89

García, M. R., Pérez, P. R., Rodríguez, H. C. \& Soto, H. M. (2004). Toxicidad de alcaloides de Erythrina americana en larvas de mosquito Culex quinquefasciatus. Revista Fitotecnia Mexicana, 27(4):297-303

Gaugler, R. (1997). Alternative paradigms for comercializing biopesticides Phytoparasitica 25(3):179-182.

Gómez-Pompa, A. 2010. Las raíces de la etnobotánica. Acta Biologica Panamensis, 1: 87-100.

Gómez, M.A. (2004). La agricultura en México y en el mundo. CONABIO. Biodiversitas, 55: 13-15.

Gómez, C.M, Rindermann, R.S., Gómez, T.L., Arce, C.I., Morán, V.Y. \& Quiterio, M.M. (2001). Agricultura orgánica de México. Datos básicos. Centro de Estadística Agropecuaria de la Secretaría de Agricultura, Ganadería, Desarrollo Rural, Pesca y Alimentación (SAGARPA), Centro de Investigaciones Económicas, Sociales y Tecnológicas de la Agroindustria y la Agricultura Mundial (CIESTAAM) de la Universidad Autónoma Chapingo (UACH). 2da. edición. México, D.F. 45 p.

Golob, P., Moss, C., Dales, M., Fidgen, A., Evans J. \& Gudrups, I. (1999). The use of spices and medicinals as bioactive protectants for grains. Food and Agriculture Organization of the United Nations Rome BULLETIN No. 137, pp. 158, FAO, Viale delle Terme di Caracalla, 00100, ISBN 92-5-104294-2, Rome, Italy.

González, G.O. 1986. Evaluación de métodos tecnificados y no tecnificados para el combate del gusano cogollero del maíz Spodoptera frugiperda (J. E. Smith) y del gorgojo del maíz (Sitophilus zeamais (Motsch) en la Chontalpa, Tabasco, México. Tesis de Maestría en Ciencias. Colegio Superior de Agricultura Tropical, Cárdenas, Tabasco.

Grainge, M. \& Ahmed, S. (1988). Handbook of plants with pest control. John Wiley. \& Sons, New York, N.Y. 469.

Grainge, M., Ahmed, S., Mitchell, W.C. \& Hylin, J.W. (1985). Plant species reportedly possessing pest-control properties-An. EWC/UH Database, pp. 1-249, Resource Systems Institute. ISBN: 0866380647, Honolulu and University of Hawaii, USA. 
Guzmán-Pantoja L.E., Guevara-Fefer P., Villarreal O.M., León R. I., Aranda E.E., Martínez, P.R., Hernández, V.V. 2010. Biological activity of Ipomoea pauciflora Martens and Galeotti (Convolvulaceae) extracts and fractions on larvae of Spodoptera frugiperda J. E. Smith (Lepidoptera: Noctuidae). African Journal of Biotechnology, 9(24): 3659-3665, (June, 2010), ISSN 1684-5315.

Hasting, R.B. (1990). Medicinal legumes of México: Fabaceae, Papilionoideae, Part one. Econ. Bot, 44: 336-348.

Isman, BM. (1997). Neem and other botanical insecticides: barriers to comercialization. Phytoparasitica, 25(4):339-344.

Isman, BM. (1999). Neem and related natural products. Hall, F. \& Menn,J.J. (eds), In: Methods in Biotechnology, Vol. 5: Biopesticides: Use and Delivery. Humana Press, Totowa . N.J. USA. p. 139-153.

Isman, M. B. (2006). Botanical insecticides, deterrents, and repellents in modern agriculture and an increasingly regulated world. Annual Review of Entomology, 51: 45-66.

Isman, M.B. (2008). Perspective botanical insecticide: for riche, for poorer. Pest Management Science, 64: 8-11.

Jackson, M.D. \& Peterson, J.K. (2000). Sublethal effects of Resin Glycosides from the periderm of sweetpotato storage roots on Plutella xylostella (Lepidoptera: Plutellidae). Journal of Economic Entomology, 93 (2): 388-393.

Jiménez, C.M. \& Rodríguez, H. C. (1990). Acción tóxica del piquerol A (terpeno) y sus derivados sobre larvas de Culex quinquefasciatus, Aedes aegypti y Spodoptera frugiperda. Resúmenes del II Simposio Nacional sobre sustancias vegetales y minerales en el combate de plagas. Sociedad Mexicana de Entomología, Oaxaca, México, p. 11.

Jiménez, C.F. \& Villar, M.C. (1990). Utilización de dos especies de plantas con propiedades tóxicas, para el combate del gusano cogollero del maíz Spodoptera frugiperda (J. E. Smith) en el C.A.E.E.A., ciclo primavera-verano.1988. Resúmenes del II Simposio Nacional sobre sustancias vegetales y minerales en el combate de plagas. Sociedad Mexicana de Entomología, Oaxaca, México, p. 16.

Juárez-Flores B.I., Jasso-Pineda Y., Aguirre-Rivera J-R. \& Jasso-Pineda I. (2010). Efecto de polvos de Asteráceas sobre el gorgojo del maíz (Sitophilus zeamais Motsch). Polibotánica, 30:123-135

Kumul, D. E. (1983). Búsqueda de plantas silvestres del Estado de Veracruz, con propiedades tóxicas contra gusano cogollero del maíz Spodoptera frugiperda J. E. Smith y mosquito casero (Culex quinquefasciatus Say). Tesis profesional. Departamento de Parasitología Agrícola. UACH, México, 76 p.

Kutchan, T. \& Dixon, R.A. (2005). Physiology and metabolism Secondary metabolism: nature's chemical reservoir under deconvolution. Current Opinion in Plant Biology, 8: 227-229.

Lagunes, T. A, Domínguez, R. R. \& Bermudes, V. L. (1982). Búsqueda de plantas nativas del Estado de México con propiedades tóxicas contra gusano cogollero, Spodoptera frugiperda J. E. Smith y mosquito casero, Culex quinquefasciatus Say. Chapingo, 7 (37):35-39.

Lagunes, T., Arenas, A., Arenas, L. \& Rodríguez, H. C. (1984). Extractos acuosos y polvos vegetales con propiedades insecticidas. CONACyT-CO-UACH-INIA-DGSV. Centro de Entomología y Acarología, Colegio de Posgraduados, Chapingo, México. 
Lagunes, T.A. \& Rodríguez, H.C. (1989). Búsqueda de tecnología apropiada para el combate de plagas de maíz almacenado en condiciones rústicas. Informe del proyecto CONACYT PTV/AI/NAL/85/3149. CONACYT-CP, 150 P.

Llorente-Bousquets, J. \& Osegueda, S. (2008). Estado del conocimiento de la biota en Capital natural de México. Vol I: Conocimiento actual de la biodiversidad. CONABIO, México, pp. 283-322.

López-Olguín, J., Budia, F., Castañera, P. \& Viñuela, E. (1997). Actividad de Trichilia havanensis Jacq. (Meliazeae) sobre larvas de Spodoptera littoralis (Boisduval) (Lepidoptera: Noctuidae). Boletín de Sanidad Vegetal Plagas, 23: 3-10.

López, P, E. \& Rodríguez, H. C. (1999). Actividad de la chilca Senecio salignus (Asteraceae) en el combate del gorgojo mexicano del frijol Zabrotes subfasciatus (Coleoptera: Bruchidae). Rodríguez, H. C. (ed.), Procceding of Memorias del Simposio Nacional sobre substancias vegetales y minerales en el combate de plagas. (5, 1999, Aguascalientes, México). p. 93-99.

López-Olguín, J., Adán, A., Ould-Abdallahi, E., Budia, F., Del Estal, P. \& Viñuela, E. (2002). Actividad de Trichilia havanensis Jacq. (Meliazeae) en la mosca mediterranea de la fruta Ceratitis capitata (Diptera:Tephritidae). Boletín de Sanidad Vegetal Plagas, 28:299306.

López, P, E. \& Rodríguez, H. C. (2006). Actividad biológica de la raíz de Senecio salignus contra Zabrotes subfasciatus en frijol almacenado. Agrociencia, 41:95-102.

Machado, C.H. \& Rodríguez, H.C. (1991). Toxicidad de Hippocratea spp (Hippocrateaceae) en larvas de Culex quinquefasciatus, Aedes aegypti (Diptera:Culicidae) y S. frugiperda (Lepidoptera: Noctuidae) en el laboratorio. Resúmenes del III Simposio Nacional sobre sustancias vegetales y minerales en el combate de plagas. Sociedad Mexicana de Entomología, Veracruz, México, p. 40.

Macías, F.A., Galindo, J.L. \& Galindo, J.C. (2007). Evolution and current status of ecological phytochemistry. Phytochemistry, 68: 2917-2936.

Magaña, P. \& Villaseñor, J. L. (2002). La flora de México, ¿se podrá conocer completamente?. Ciencia, 66: 24-26.

Martínez, P. S. (1983). Búsqueda de plantas medicinales con propiedades insecticidas contra el gusano cogollero Spodoptera frugiperda (J. E. Smith) (Lepidoptera: Noctuidae). Tesis de licenciatura. Depto. de parasitología agrícola. UACH, Chapingo, México, 83 p.

Martínez-Tomás, S., Pérez-Pacheco, R., Rodríguez Hernández, C., Ramírez-Valverde, G. \& Ruíz-Vega, J. (2009). Effects of an aqueous extract of Azadirachta indica on the growth of larvae and development of pupae of Culex quinquefasciatus. African Journal of Biotechnology, 8(17): 4245-4250.

Miranda, F. 1952. La Vegetación de Chiapas. Ediciones del Gobierno del estado de Chiapas, pp.319, Tuxtla Gutiérrez, Chiapas, México.

Navarrete, A., Reyes, B., Sixto,C., Rodríguez, C. \& Estrada E. (1991). Alfa-Sanshool principio activo larvicida de la corteza de Zanthoxyllum liebmannianum (ENGL.) P. Wilson. Procceding of Memorias del III Simposio Nacional sobre sustancias vegetales y minerales en el combate de plagas, p. 41, Veracruz, México.

Ortega, A. L. \& Hernández, R. C. (1991). Evaluación en campo de polvos vegetales contra el gusano cogollero del maíz (Spodoptera frugiperda (J.E. Smith) (Lepidoptera: Noctuidae) en Tepetates, Veracrúz. Procceding of Memorias del tercer Simposium 
Nacional sobre sustancias Vegetales y Minerales en el Combate de Plagas, Veracrúz, México. p. 1-5.

Ortega, A.L. \& Rodríguez, H.C. (1991). Utilización de gordolobo Gnaphalium inortatum (Asteraceae) para la protección de maíz almacenado en condiciones rústicas. Resúmenes del III Simposio Nacional sobre sustancias vegetales y minerales en el combate de plagas. Sociedad Mexicana de Entomología, Veracruz, México, pp. 15-19.

Ortega, A.L., Rodríguez, H.C. \& Tamayo, M.F. (1998). Extractos acuosos de Nim Azadirachta indica como alternativa de manejo de la mosquita blanca en el cultivo de tomate. Resumen del I Simposio Internacional y IV Nacional sobre sustancias vegetales y minerales en el combate de plagas. Sociedad Mexicana de Entomología, Acapulco, Gro., México, pp. 39-48.

Osuna, L.E. (2005). Uso del Neem para la elaboración artesanal de plaguicidas. Folleto Técnico No. 10. Ed. Instituto Nacional de Investigaciones Forestales, Agrícolas y Pecuarias, Centro de Investigación Regional del Noroeste, Campo Experimental Todos Santos, La Paz, B.C.S., México. pp. 32.

Pacheco, S. C., Villa, A. P., Rodríguez, H. C., Zamilpa, Á. A, Hernández, G. H. \& Jiménez, P. A. (2009). Respuesta del picudo del agave Scyphophorus acupunctatus Gyll. hacia extractos hidroalcohólicos de higuerilla Ricinus communis L. Procceding of Quinto Congreso Estatal: La Investigación en el Posgrado. Universidad Autónoma de Aguascalientes. Aguascalientes, Ags. México.

Paéz, L.A. (1987). El uso de polvos vegetales e inertes minerales como una alternativa para el combate del gorgojo del maíz Sitophilus zeamais Mots. (Coleotera: Curculionidae) en maíz almacenado. Tesis de Maestría. Colegio de Postgraduados, Chapingo, México, $102 \mathrm{p}$.

Pedraza, F.J.J. \& Albarrán, M.M. (1986). Utilización de sustancias acuosas vegetales para el combate del gusano cogollero del maíz Spodoptera frugiperda J.E. Smith (Lepidoptera: Noctuidae) en San Antonio del Rosario. Tlatlaya Estado de México. Tesis de Licenciatura. UAEM. Facultad de Ciencias Agrícolas, Cerillo, México.

Pereda-Miranda, R. \& Bah, M. (2003). Biodynamic constituents in the Mexican morning glories: purgative remedies transcending boundaries. Current Topics in Medicinal Chemistry, 3: 111-131.

Pérez, H. M. A. (2001). Prólogo. In: Rendón, A. B., Rebollar, D. S., Caballero, N. J. y Martínez, A. M. (eds.), Plantas, cultura y sociedad estudio sobre la relación entre seres humanos y plantas en los albores del siglo XXI, pp. 7-11, Universidad Autónoma Metropolitana-Iztapalapa y Secretaría del Medio Ambiente, Recursos Naturales y Pesca, pp. 315, ISBN: 970-654-782-7, México, D. F.

Philogène, B. J., Regnault-Roger, C. \& Vincent. C. (2003). Productos fitosanitarios insecticidas de origen vegetal: promesas de ayer y de hoy. In: C. Regnault-Roger, B. J. Philogène, C. Vincent (eds.), Biopesticidas de origen vegetal., Mundi Prensa. pp. 1-18, México.

Prakash, A. \& Rao, J. (1997). Botanical pesticides in agriculture. Ed. Lewis Publishers, New York, USA, 461p.

Pushpalatha, E. \& Muthukrishnan, J. Efficacy of two tropical plants extracts for the control of mosquitoes. Journal of Applied Entomology, 1999; 123: 369-73. 
Ramírez-Moreno, L., García-Barrios, L., Rodríguez, C., Morales, H. \& Castro, R. A. (2001). Evaluación del efecto insecticida de extractos de plantas sobre Leptophobia aripa elodia. Manejo Integrado de Plagas, 60:50-56.

Ramos, L. M., Pérez, G. S., Rodríguez, H. C., Guevara, F. P. \& Zavala, S. M. (2010). Activity of Ricinus communis (Euphorbiaceae) against Spodoptera frugiperda (Lepidoptera:Noctuidae). African Journal of Biotechnology, 9(9): 1359-1365.

Rodríguez, H, C., Lagunes, T. A., Domínguez, R. R. \& Bermúdez, V. L. (1982). Búsqueda de plantas nativas del Estado de México con propiedades tóxicas contra el gusano cogollero, Spodoptera exigua J.E. Smith, y mosquito casero, Culex quinquefasciatus Say. Chapingo, 37-38:35-39

Rodríguez, H.C. (1990). Actividad insecticida de cancerina (Hippcratea excelsa: Hippocrateaceae) en siete especies de insectos de importancia económica. Resúmenes del II Simposio Nacional sobre sustancias vegetales y minerales en el combate de plagas. Sociedad Mexicana de Entomología, Oaxaca, México, p. 10.

Rodríguez, H. C. (1990). Perspectivas del uso de plantas con propiedades insecticidas. Procceding of Memorias del Simposio Nacional sobre sustancias vegetales y minerales en el combate de plagas, (11, 1990, Oaxaca, México). p. 176-187.

Rodríguez, H.C. (1991). Evaluación en campo de polvos vegetales y minerales contra el gusano cogollero del maíz (Spodoptera frugiperda (J. E. Smith) (Lepidoptera: Noctuidae)) en Tepetates, Veracruz. Resúmenes del III Simposio Nacional sobre sustancias vegetales y minerales en el combate de plagas. Sociedad Mexicana de Entomología, Veracruz, México, p. 1.

Rodríguez, H. C. \& Lagunes, T. A. (1992). Plantas con propiedades insecticidas; resultados de pruebas experimentales en laboratorio, campo y granos almacenados. Agroproductividad (México), 1:17-25.

Rodríguez, H. C. (1993). Fitoinsecticidas en el combate de insectos: Bases prácticas de la agroecología en el desarrollo centroamericano. In: Manejo de plagas en el sistema de producción orgánica. Guatemala, ALTERTEC/HELVETAS/ CLADES. p. 112125, México.

Rodríguez, H. C. (1996). Recetas para el control de insectos. In: Control alternativo de insectos plaga. Rodríguez H, C. (ed), Colegio de Postgraduados and Fundación Mexicana para la educación ambiental, A.C. p. 46-51, Tepoztlán, Edo. de México, México.

Rodríguez, H. C. (1997). Insecticidas vegetales y agricultura orgánica. In: Evento de aprobación en certificación de agricultura orgánica. Colegio de Postgraduados. p. 162-179, Montecillo, México.

Rodríguez, H.C. (1999). El paraíso Melia azedarach (Meliaceae) como alternativa de manejo de plagas. Avances en la investigación 1999, Colegio de Postgraduados, Instituto de Fitosanidad, México, pp. 1-3.

Rodríguez, H. C. (2000). La higuerilla: una alternativa contra plagas. Boletin de RAPAM, 28: 7-11.

Rodríguez H, C., Lagunes, T,A., Domínguez, R. \& Bermúdez, V.L. (1982). Búsqueda de plantas nativas del Estado de México con propiedades tóxicas contra el gusano cogollero, Spodoptera exigua J.E. Smith, y mosquito casero, Culex quinquefasciatus Say. Revista Chapingo 7 (37-38):35-39. 
Rodríguez, H. C. \& López, P. E. (2001). Actividad insecticida e insectistática de la chilca (Senecio salignus) sobre Zabrotes subfasciatus. Manejo Integrado de Plagas, 59:19-26.

Rodríguez, H. C. (2006). Plantas Contra Plagas 1. Potencial Práctico de Ajo, Anona, Nim, Chile y Tabaco. Ed. 30 Colegio de Post Graduados Red de Acción sobre plaguicidas y Alternativas en México (RAPAM) y Red de Acción en Plaguicidas y sus Alternativas para América Latina (RAP-AL). Texcoco, Edo. de México, México.

Rodríguez-López, V., Figueroa-Suárez M., Rodríguez T. \& Aranda E. (2007). Insecticidal activity of Vitex mollis. Fitoterapia, 78:37-39.

Rodríguez, H, C. (2008). Alternativas para el manejo integrado de gorgojos en graneros rústicos. LEISA revista de agroecología, Marzo: 32-35.

Rodríguez, H.C. (2008). Opciones biorracionales para el manejo de plagas. In: Manejo integrado de plagas. Toledo J. \& Infante F. (Eds). Ed Trillas. pp. 183-191.

Rodríguez, H. C. (2011). Curso básico para inspectores en agricultura orgánica. Celaya, Guanajuato, México. pp. 24.

Romo, O.J., Rodríguez, H.C. (1988). Combate d la conchuela del frijol Epilachna varivestis Muls. (Coccinellidae: Coleoptera) con extractos acuosos vegetales en Chango, Edo. de México. Resúmenes del XXIII Congreso Nacional Entomología. Morelia, Michoacán, México. p. 282.

Salehzadeh, A., Akhkha, A., Cushley, W., Adams, R.L.P., Kusel, J.R. \& Strang, R.H.C. (2003). The antimitotic effect of the neem terpenoid azadirachtin on cultured insect cells. Insect Biochemistry and Molecular Biology, 33: 681-689.

Saxena, S.C. \& Sumithra, L. (1985). Laboratory evaluation of leaf extract of a new plant to suppress the population of malaria vector Anopheles stephensi Liston (Diptera: Culicidae). Current Science, 54:201- 2.

Sengonca, C. \& Brüggen, K.U. 1991. Untersuchungenüber die Wirkung wäßriger Extrakte aus Quassia amara (L.) auf Getreideblattlä use. Jorunal of Applied Entomology, 112, 211-215.

Scott, R.H., O’Brien, K., Roberts, L., Mordue, W. \& Mordue, L. J. (1999). Extracellular and intracellular actions of azadirachtin on the electrophysiological properties of cultured rat DRG neurones. Comp. Biochem. Physiol. C Pharmacol Toxicol Endocrin, $123,85-93$.

Scott, I.M., Jensen, H., Scot, J.G., Isman, M.B., Arnason, J.T. \& Philogèine, B. J. (2003). Botanical insecticides for controlling agricultural pests: Piperamines and the Colorado Potato Betle Leptinotarsa decemlineata Say (Coleoptera: Chysmelidae). Archives of insect Biochemistry Physiology, 54: 212-225.

SEMARNAT. (2011). URL:

http://app2.semarnat.gob.mx/tramites/Doctos/DGGIMAR/Guia/07015AD/riesgos.pdf.

Sengonca, C., Bru, S. A., Akhkha, A., Cushley, W., Adams, R.L., Kusel, J.R. \& Strang, R.H. (2003). The antimitotic effect of the neem terpenoid azadirachtin on cultured insect cells. Insect Biochemistry Moleculra Biology, 33, 681-689.

Shaalan, E., Canyon, D., Faried, M.W., Abdel-Wahab, H. \& Mansour, A. H. (2005). A review of botanical phytochemicals with mosquitocidal potential. Environment International, 31: 1149-1166. 
Silva, A. G., Lagunes, T. A., Rodríguez, M. C. \& Rodríguez, L. D. (2002). Insecticidas vegetales: una vieja y nueva alternativa para el manejo de plagas. Manejo Integrado de Plagas y Agroecología, (Costa Rica), 66: 4-1 2.

Singh, R.N. \& Saratchandra, B. (2005). The development of botanical products with special reference to seri-ecosystem. Caspian Journal of Environmental Sciences, 3 (1): 1-8.

Siqueira, H., Alvaro, A., Guedes, Raul, N.C. \& PicanÇo, M.C. (2000). Insecticide resistance in population of Tuta absoluta (Lepidoptera: Geleiidae). Agricultural and Forest Entomology, 2: 147-153.

Toledo, T.E. (2001). Propiedades insecticidas de algunas especies de Ipomoea (Convolvulaceae) del Estado de Morelos. Tesis de Licenciatura. Facultad de Estudios Superiores Iztacala. Universidad Nacional Autónoma de México. Edo. de México, México, pp. 51.

Trujillo, V. R., \& García-Barrios, L. (2001). Conocimiento indígena del efecto de plantas medicinales locales sobre las plagas agrícolas de los altos de Chiapas, México. Agrociencia, 35(6):685-692.

Trysyono, A. \& Whalon, M. (1999). Toxicity of neem applied alone and in combinations with Bacillus thuringiensis to Colorado potato beetle (Coleoptera: Chysomelidae). Journal of Economic Entomology, 92: 1281-1288.

Vera, C.L., Hernández, V.V., León, R.I., Guevara, F.P. \& Aranda, E.E. (2009). Biological activity of methanol extracts of Ipomoea murucoides Roem et Schult on Spodoptera frugiperda J. E. Smith. Journal of Entomology, 6(29): 109-116.

Villavicencio-Nieto, M. A., Pérez- Escandón, B. E. \& Gordillo-Martínez, A. J. (2010). Plantas tradicionalmente usadas como plaguicidas en el Estado de Hidalgo, México. Polibotánica, 30:193-238.

Villegas, E.S. (1989). Incorporación de Hippocratea excelsa (Hippocrateaceae) y cuatro polvos minerales en maíz encostalado para evitar el daño de insectos en Lerma, Estado de México. Tesis de Licenciatura de Ingeniero Agrónomo, Especialidad en Parasitología Agrícola. Universidad Autónoma Chapingo, Departamento de Parasitología Agrícola, México, 76 p.

Villegas, C., Martínez, V. M. \& Baldomero, E. (2009). Antifeedant activity of anticopalic acid isolated from Vitex hemsleyi. Journal of Biosciences, 64:502-508.

Villanueva, J.J.A. (1988). Actividad biológicas de extractos acuosos de frutos vegetales sobre larvas de primer instar del gusano cogollero del maíz Spodoptera frugiperda (J. E. Smith) (Lepidoptera: Noctuidae), bajo condiciones de laboratorio. Tesis profesional. Departamento de Parasitología Agrícola-UACH, Chapingo, México, 77 p.

Vyvyan, J.R. (2002). Allelochemicals as leads for news herbicides and agrochemicals. Tetrahedron,58: 1631-1646.

Vovides, A. P., Linares, E. \& Bye, R. (2010). Jardines botánicos de méxico: historia y perspectivas. Ed. Secretaría de Educación de Veracruz del Gobierno del Estado de Veracruz de Ignacio de la Llave, pp. 232. ISBN: 978-607-7579-18-2, Veracruz, México.

Xing-An, C., Jian-Jun, Xie, Mei-Ying, Hu, Yan-Bo, Z. \& Jing-Fei, H. (2011). Induction of Intracellular Ca2+ and $\mathrm{pH}$ Changes in Sf9 Insect Cells by Rhodojaponin-III, A Natural Botanic Insecticide Isolated from Rhododendron molle. Molecule, 16: 31793196.

Wink, M. \& Schimmer, O. (1999). Modes of action of defensive secondary metabolites. In: Michael Wink (ed.), Functions of plant secondary metabolites and their exploitation 
in biotechnology. Annual Plant Reviews, Vol. 3., Sheffield Academic Press LTD. p. 16-130, USA-Canada.

Weinzierl, R.A. (2000). Botanicals insecticides, soaps, and oils. In: Rechcigl J.E., Rechcigl, N.A. (ed.), Biological and Biotechnological Control of Insect Pests. CRC Press LLC. Boca Raton, Florida, p. 101-121, EE. UU.

Zaid, M. \& Nozzolillo, C. (2000). 1-o- galloyl-L-rhamnose from Acer rubrum. Phytochemistry, 52: 1629-1361. 


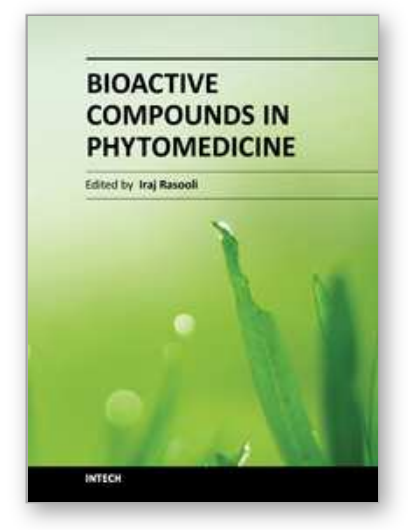

\author{
Bioactive Compounds in Phytomedicine \\ Edited by Prof. Iraj Rasooli
}

ISBN 978-953-307-805-2

Hard cover, 218 pages

Publisher InTech

Published online 18, January, 2012

Published in print edition January, 2012

There are significant concerns regarding the potential side effects from the chronic use of conventional drugs such as corticosteroids, especially in children. Herbal therapy is less expensive, more readily available, and increasingly becoming common practice all over the world. Such practices have both their benefits and risks. However, herbal self-therapy might have serious health consequences due to incorrect self-diagnosis, inappropriate choice of herbal remedy or adulterated herbal product. In addition, absence of clinical trials and other traditional safety mechanisms before medicines are introduced to the wider market results in questionable safe dosage ranges which may produce adverse and unexpected outcomes. Therefore, the use of herbal remedies requires sufficient knowledge about the efficacy, safety and proper use of such products. Hence, it is necessary to have baseline data regarding the use of herbal remedies and to educate future health professionals about various aspects of herbal remedies.

\title{
How to reference
}

In order to correctly reference this scholarly work, feel free to copy and paste the following:

Ludmila Elisa Guzmán-Pantoja, Laura P. Lina-Garcia, Graciela Bustos-Zagal and Victor M. HernándezVelázquez (2012). Current Status: Mexican Medicinal Plants with Insecticidal Potential, Bioactive Compounds in Phytomedicine, Prof. Iraj Rasooli (Ed.), ISBN: 978-953-307-805-2, InTech, Available from:

http://www.intechopen.com/books/bioactive-compounds-in-phytomedicine/current-status-mexican-medicinalplants-with-insecticidal-potential

\section{INTECH}

open science | open minds

\section{InTech Europe}

University Campus STeP Ri

Slavka Krautzeka 83/A

51000 Rijeka, Croatia

Phone: +385 (51) 770447

Fax: +385 (51) 686166

www.intechopen.com

\section{InTech China}

Unit 405, Office Block, Hotel Equatorial Shanghai

No.65, Yan An Road (West), Shanghai, 200040, China

中国上海市延安西路65号上海国际贵都大饭店办公楼405单元

Phone: +86-21-62489820

Fax: $+86-21-62489821$ 
(C) 2012 The Author(s). Licensee IntechOpen. This is an open access article distributed under the terms of the Creative Commons Attribution 3.0 License, which permits unrestricted use, distribution, and reproduction in any medium, provided the original work is properly cited. 